\title{
Shallow marine bioerosion: preliminary results of an experimental study
}

\author{
RICHARD G. BROMLEY, NILS-MARTIN HANKEN and ULLA ASGAARD
}

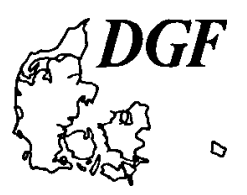

Bromley, R. G., Hanken, N.-M. \& Asgaard, U. Shallow marine bioerosion: preliminary results of an experimental study. Bull. geol. Soc. Denmark, vol. 38, pp.85-99, Copenhagen, April 25th, 1990. https://doi.org/10.37570/bgsd-1990-38-09

\begin{abstract}
In order to investigate long-term bioerosional effects on carbonate rock surfaces in shallow marine settings, test blocks were placed off a rocky shore on Rhodes, Greece at $-3 \mathrm{~m}$ to $-17 \mathrm{~m}$. Retrieval of blocks each year allowed the progress of bioerosion to be monitored. Rapid colonization by endolithic algae was followed by recruitment of browsing chitons and echinoids. The first boring sponges arrived in year 1 but were barely visible until year 2 . After six years, stable blocks were deeply bioeroded. The history of community development varies considerably from block to block, largely depending on degree of disturbance. Physical disturbance consists of block tumbling as a function of water turbulance levels and the block's weight and shape; biological disturbance comprises the activity of rasping herbivores. The surfaces reveal a mosaic of successional stages in community development. Equilibrium has not yet been established on stable blocks; unstable blocks remain at a pioneer phase of community succession. The slow progress implies that, in the fossil record, well bioeroded substrates such as skeletons and hard-grounds represent several years rather than months of depositional hiatus.
\end{abstract}

R. G. Bromley \& U. Asgaard, Institut for Historisk Geologi og Palarontologi, Øster Voldgade 10, 1350 Copenhagen K, Denmark. N.-M. Hanken, Institutt for Biologi og Geologi, P.O. Boks 3085-Guleng, 9001 Tromsø, Norway, October 1st 1989.

"In 1871 a vessel ladenwith marble was sunk in Long Island sound, and according to Prof. Verrill, the boring sponge has penetrated the exposed parts of the blocks for a depth of two or three inches from the surface" (Ryder 1879, p. 279).

\section{Introduction}

Bioerosion is the biological breakdown of hard substrates by boring, rasping, etching and abrading organisms. The process is active wherever hard substrate is exposed to marine water for longer periods of time. Carbonate rocks and skeletons are by far the most susceptible substrates to bioerosion, owing to their chemical solubility and low level of hardness, but non-carbonate rocks also are subjected to physical wasting by organisms (Warme 1975; Golubic \& Schneider 1979; Fischer 1981).

The immediate result of the process is the creation of a surface sculpture on the substrate, including distinctive borings. This sculpture is eminently recognizable in fossil condition and data supplied by bored surfaces can be used in palaeoenvironmental analyses and basin reconstruction (Ekdale et al. 1984) and the evolution of the bioerosion ecosystem (e.g., Kobluk et al. 1976; Palmer 1982).

Unfortunately, we know too little about the biology of the bioerosion process in order to refine hard substrate ichnology as a palaeontolog- ical tool. The recent study by Wilson (1987), for example, indicates some useful aspects of fossil hard substrate communities; however, we know little of the speed at which the process proceeds, or the ecological dynamics of community succession of rockgrounds.

What is the minimum duration of a sedimentary hiatus represented by a well-bored rockground? What is the significance of a hardground surface lacking bioerosion? Can different bioerosion sculptures and trace fossils inform us about the general environment, or microenvironments, on the substrate surface? We have inadequate answers to these questions. In order to improve our knowledge of the process, we designed a long-term experiment involving the placing of carbonate substrates at strategic places on a rocky seafloor. We were able then to watch the progress of colonization over known intervals of time. This experiment has now run for six years and it is intended to continue to collect data for at least a further four years. However, we have so many new observations already that a preliminary statement is warranted at this stage. 


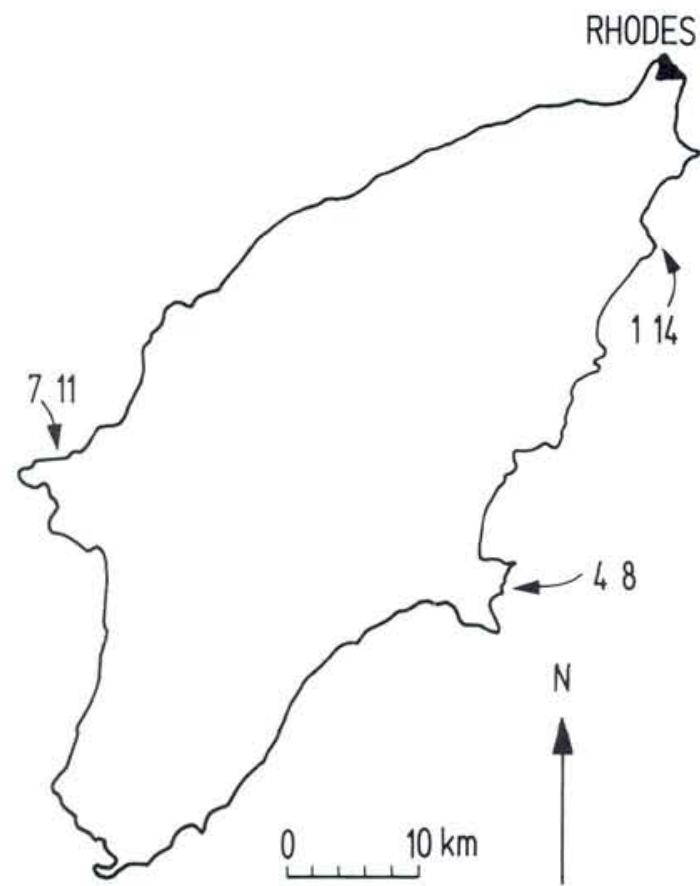

Fig. 1. Outline map of the island of Rhodes, indicating the localities mentioned in the text.

\section{Methods}

Placing substrates experimentally on the seafloor in order to monitor their colonization by encrust- ing communities is a common procedure (e.g., Martindale 1976; Sutherland \& Karlson 1977; Mook 1981; Davis \& Wilce 1987). The majority of these projects have involved epilithic communities. Among the relatively few such studies on bioeroding organisms, most have concerned micro-organisms (e.g., May \& Perkins 1972; Perkins \& Tsentas 1976; Bélanger \& Cardinal 1977; Kobluk \& Risk 1977; Tudhope \& Risk 1985). Microbial communities probably attain equilibrium within a year or less, so that a short-term project is sufficient (Perkins \& Tsentas 1976; Poulicek et al. 1981). On the other hand, community succession of macro-organisms may take several years to reach equilibrium, and no studies of sufficient duration appear to have been undertaken. Rützler (1975) and Tunnicliffe (1982) monitored boring sponges for one and two years respectively.

The need for a long-term study covering at least five and possibly ten years led us to initiate the present project. The limestone coast of Rhodes, Greece was chosen for the locale, since the biology of the seafloor there is relatively well known. Using skin diving and floatation devices, large numbers of test blocks of marble and a few of limestone were placed on the limestone seafloor at 16 localities ranging in water depth from $3 \mathrm{~m}$ to $17 \mathrm{~m}$ and representing different hydrodynamic conditions (fig. 1).

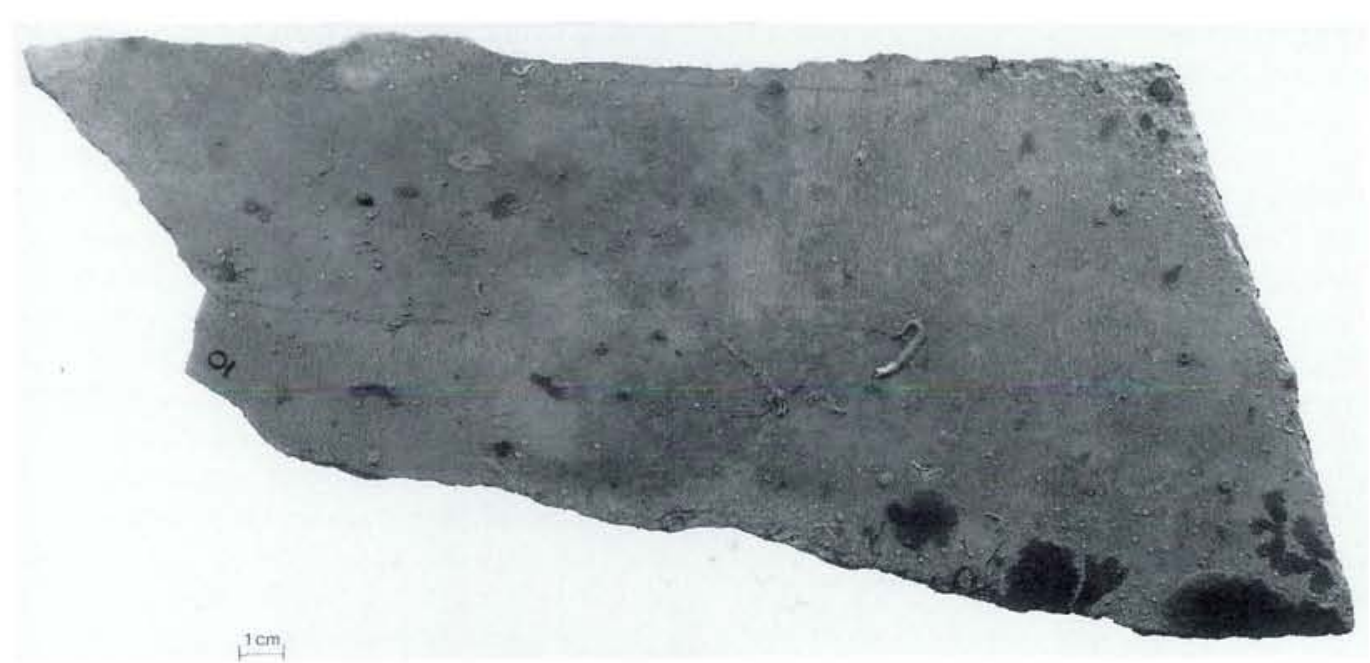

Fig. 2, Block no, 8, a thin slab polished on both sides and rough around the edges. This was on the seafloor at $-8 \mathrm{~m}$ at locality 11 for 2 years. $\times 0.5$. 


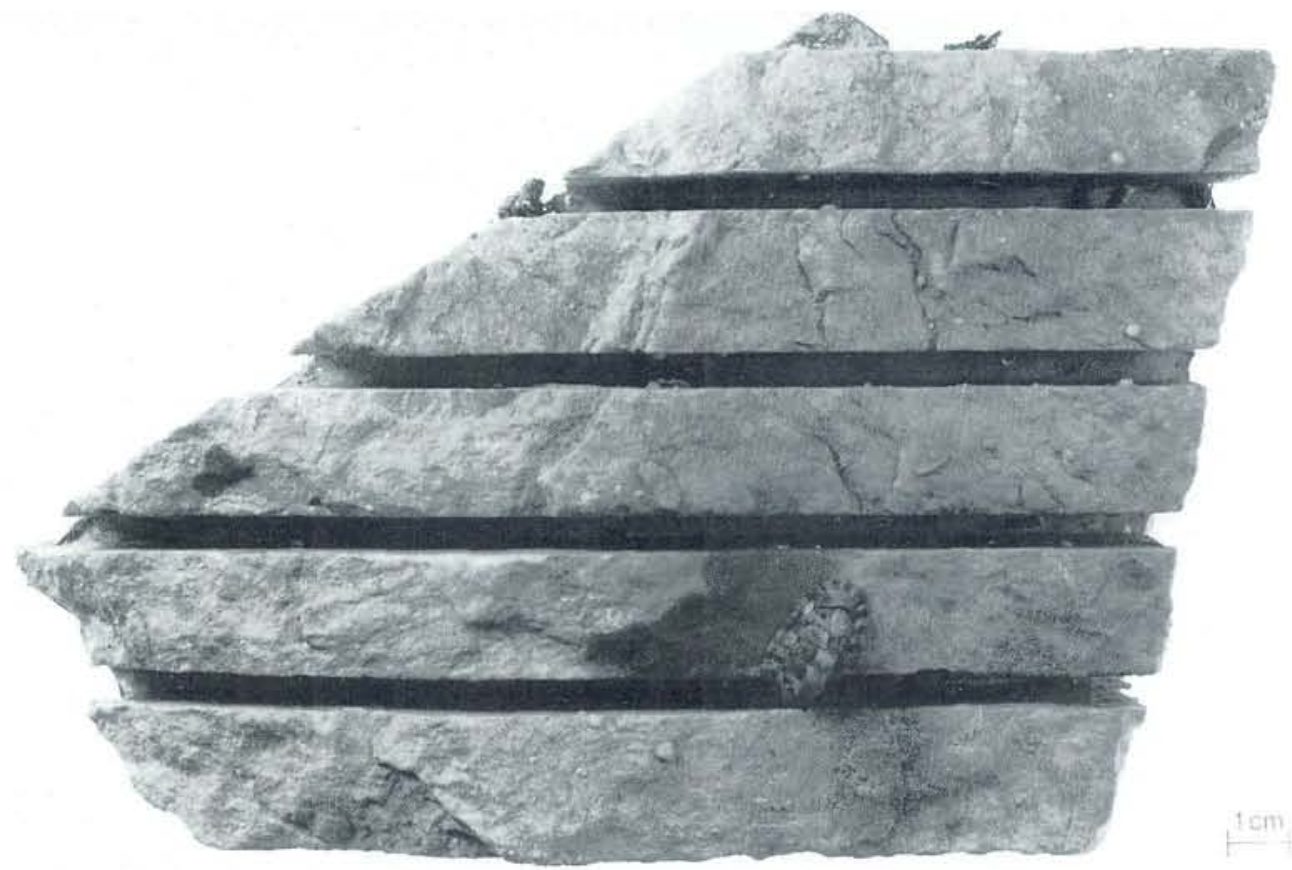

Fig. 3. Block no. 7, a slitted block. Base and slits sawn, all other parts rough fracture surfaces. The block lay on the seafloor at $-17 \mathrm{~m}$ with slits downward for 2 years at locality 8 . Slits $2 \mathrm{~cm}$ apart.

\section{The substrates}

In the quest for large amounts of tight, pure calcium carbonate rock of uniform quality, we found an ideal source in the abundant waste product of the Greek building industry. Pure white, homogeneous marble was chosen, together with a few pieces of tight, pure limestone. Provenance of the rocks is unknown, but in the present context this is no disadvantage. Thin sec- tions were prepared to document the lithology of the substrate material.

\section{Form}

The test blocks have two forms: (1) thin slabs and (2) slitted blocks. The smaller slabs are $2 \mathrm{~cm}$ thick, and were chosen for use with radiography at a later date. On each slab, some surfaces origi-

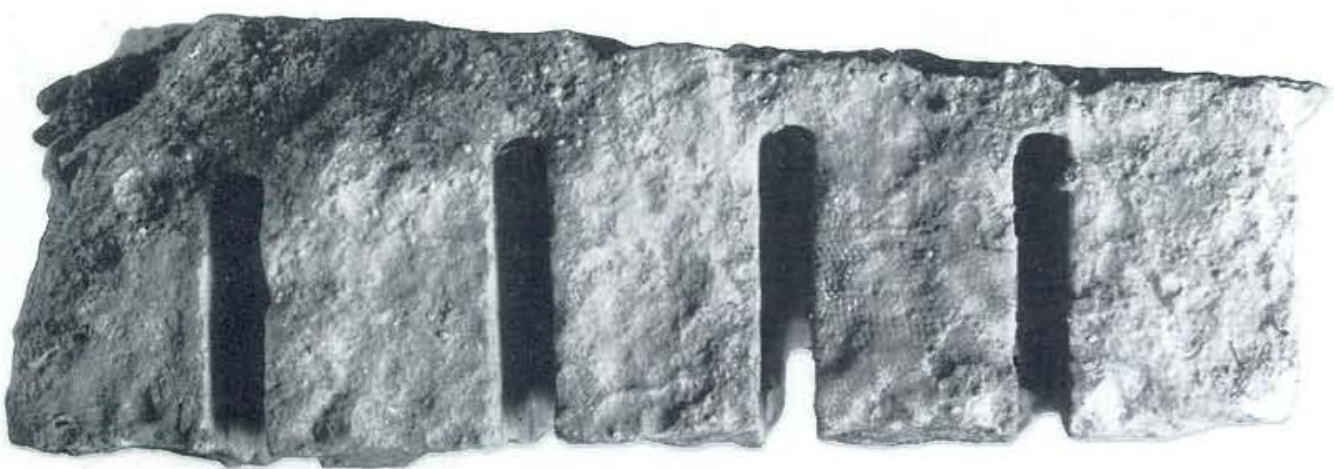

Fig. 4. End-view of test block no. 7 seen in fig. 3. Note the cuspate sculpture produced by chiton bioerosion, which has also generally smoothed the fracture surface. Bryozoans and serpulid polychates have encrusted the surface locally. Orientated slits-down on seafloor. Slits $2 \mathrm{~cm}$ apart. 


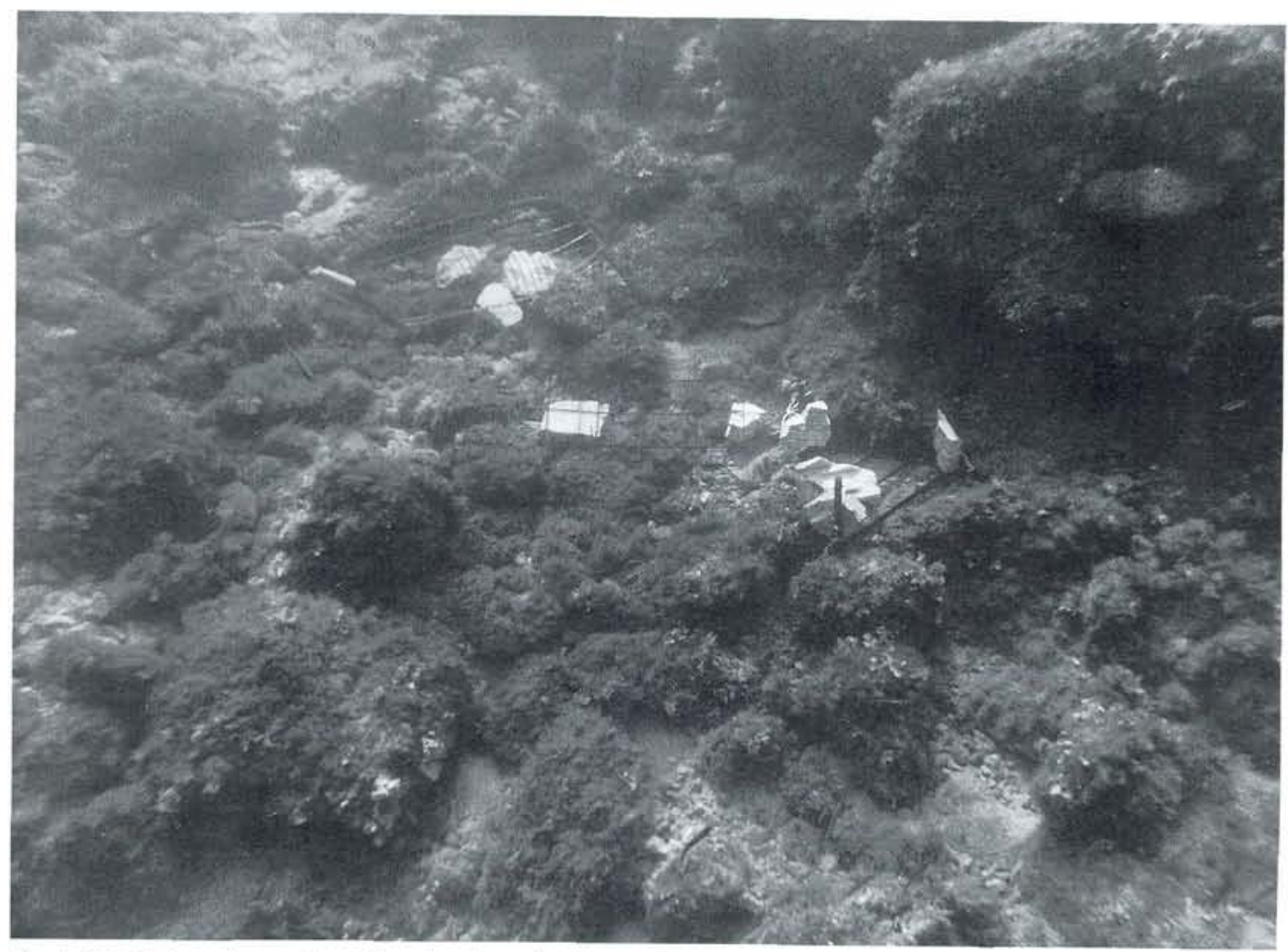

Fig. 5. Test blocks resting on the seafloor in $-8 \mathrm{~m}$ at locality 11 . The samples are bound to metal frames as this site is exposed to winter storms.

nally were smooth or polished while others were rough fracture surfaces (fig. 2).

The slitted blocks are the base pieces discarded after parallel wire saws have cut large facing slabs of marble. The deep slits are $5 \mathrm{~mm}$ wide and $2 \mathrm{~cm}$ apart, and provide varied microenvironments of protection and concealment for settling organisms (figs 3 \& 4).

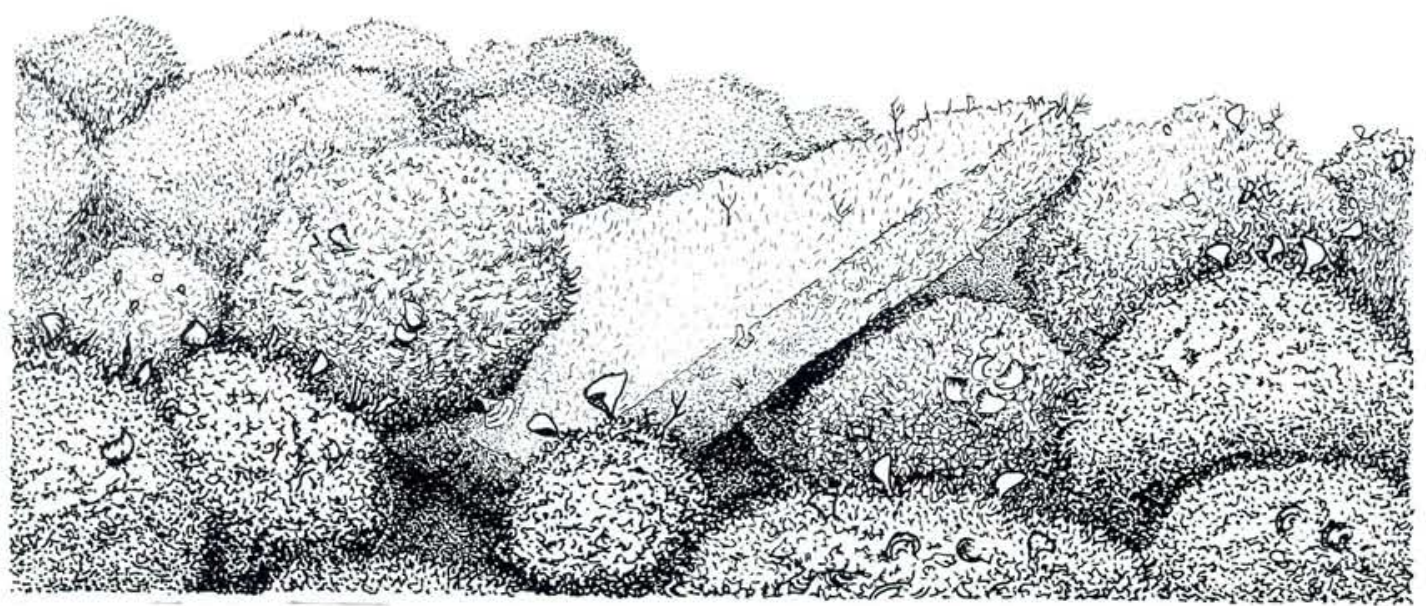

Fig. 6. Sketch of test block no. 3 as it lay on the seafloor at locality $7(-3 \mathrm{~m})$. An impression is given of the several contrasting microenvironments to which the surfaces are exposed, and the gradual to sharp boundaries between these. The block is $2 \mathrm{~cm}$ thick. 


\section{Size}

Initially, small substrates, most weighing from 1 to $3 \mathrm{~kg}$ were used. However, most of those in shallow localities were lost in winter storms in the first year. The newly laid blocks were found to be relatively unstable in turbulent conditions compared to the boulders of similar size among which they lay. New batches were laid out, and whereas larger blocks $(5-30 \mathrm{~kg})$ were deposited singly, smaller ones were tied securely to iron or plastic frames to increase their stability.

When, after the first years, a relationship between amount of bioerosion and the stability or weight of the substrate had been observed, a third set of test blocks was deposited, weighing 10 to $50 \mathrm{~kg}$. These specimens have not yet been sampled.

Except in the most turbulent sites, anchoring of blocks has been avoided, so as to simulate natural conditions of cobble stability as closely as possible (figs $5 \& 6$ ).

\section{Sampling the substrates}

The localities have been visited annually, in October. Every year, a series of samples has been lifted from each locality in order to supply evidence of the progressive degradation (and encrustation) of the substrates.

No attempt was made in this first part of the project to photograph samples and return them to the seafloor. It is known that physical disturbance can markedly increase the growth rate of some sponges (Rützler 1975; Ayling 1981). We were therefore careful to disturb the substrates as little as possible.

General photography of samples in situ has documented the natural year-by-year movement of blocks in shallower settings (fig. 5). Macrophotography was attempted of samples in situ, but most surfaces were so covered by algal turf and hydroids that results were unusable (fig. 7). Cleaning the surfaces for photography would have disturbed the substrates unduly, so this was avoided.

Raised blocks were rinsed in fresh water and soft epiliths were removed; the blocks were then photographed and dried. In the laboratory the blocks were re-photographed and sawn into sub- samples. Thin sections were made and borings radiographed. The borings ultimately will be cast in epoxy after spicule samples have been taken from sponge tissue.

\section{The seafloor environment}

All localities have been chosen in rockground situations, either in boulder fields or on clean rock surfaces. A variable amount of sand is trapped in pockets among the boulders. Localities were chosen that are free from local pollution, and annual monitoring showed no indication of interference from human activities.

The local rock is predominantly a slightly metamorphosed Jurassic limestone, Cretaceous at Loc.11 (Orombelli \& Pozzi 1967). It is tight and homogeneous, and only locally dolomitized or chertified. The natural seafloor contains a thriving, mature endolithic community and supports a guild of epilithic algal rasping and browsing animals. To all intents and purposes, the country rock and the test blocks should be more or less identical as experienced by the bioeroding community.

\section{Results}

When first placed on the seafloor, the new samples are spectacularly visible, owing to their shining white colour. After one year, they remain somewhat paler than the surrounding rocks, and it is only after two years that they are completely camouflaged.

\section{The first year}

Microendolithic invasion. Samples raised after a single year on the seafloor have suffered some alteration. The general change in colour is due to invasion by endolithic algae and cyanophytes, producing pink, greenish and blue-green or grey areas respectively. (Endolithic fungi and bacteria no doubt also are present.) Parts of the block that were covered in sediment remain apparently pristine. The endolithic microbes penetrate the first millimetre or so of substrate densely, as seen in thin sections made perpendicular to the surface. The microbial invasion of carbonate on the sea- 


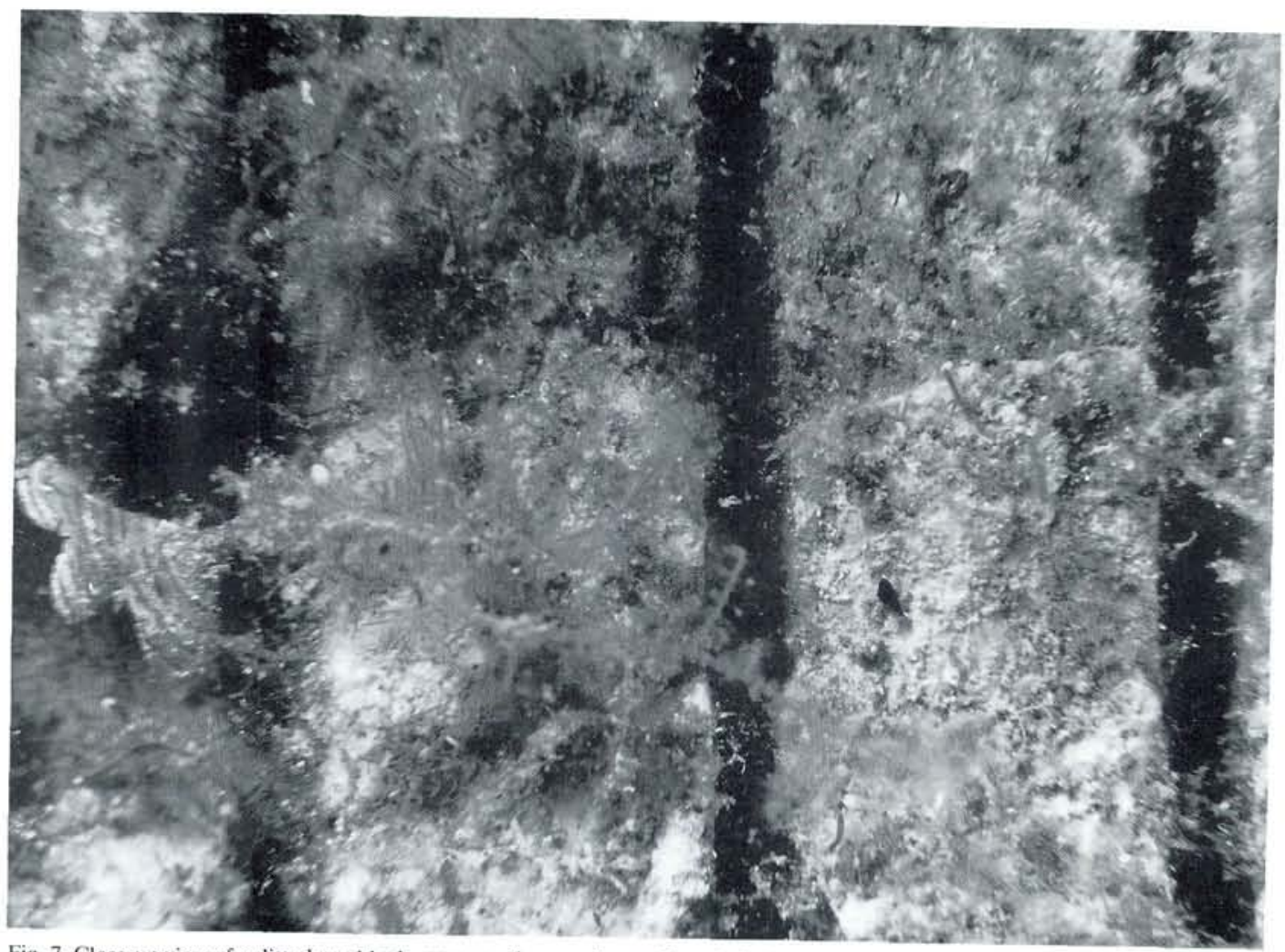

Fig. 7. Close-up view of a slitted test block, upper surface, on the seafloor $(-3 \mathrm{~m})$ at locality 14 . The photograph was taken in October when the meadow of summer epilithic algae is beginning to die off. Slits $2 \mathrm{~cm}$ apart.

floor has been demonstrated many times to be a rapid process (e.g., Kobluk \& Risk 1977).

Microenvironmental polarity. Whereas the invasion of algae and cyanophytes affects all surfaces exposed to seawater and light, all other changes show a strongly localized distribution. The attitude of the sample on the seafloor determines the orientation of these microenvironments.

The upper surface. The sample surfaces that are directed upwards become overgrown by a meadow consisting chiefly of soft green, red and brown algae and hydroids (figs $6 \& 7$ ). When the samples are inspected in October, the growth season for these is over and the surfaces are covered with a dense fluff that is decomposing. During the summer, however, this baffle system collects fine sediment that thinly covers the surface and is bound there by filamentous algae. Bioerosion of the upper substrate surface is largely limited to the endolithic microbes mentioned above.
In subsequent years, this surface shows little change, (unless occupied by an adult echinoid) and it would appear that decay of the epilithic meadow and increased turbulence in winter annually removes the sediment film and allows fresh colonization next summer. The trapped sediment film, however, tends to inhibit the settling of endolithic animals.

The lower surface. Underneath the sample, as it lies on the irregular seafloor, there is normally free access to water, but there is reduced illumination and no significant sedimentation. Under these conditions, encrusting red algae thrive, competing for space with serpulid polychaetes and bryozoans. In subsequent years, many other vagile and stationary epibenthic organisms augment the community diversity. Fleshy algae and hydroids are subordinate.

Chiton and echinoid browsing. Certainly the most marked event on the samples in their first year of exposure to sea water is the arrival of chitons and 


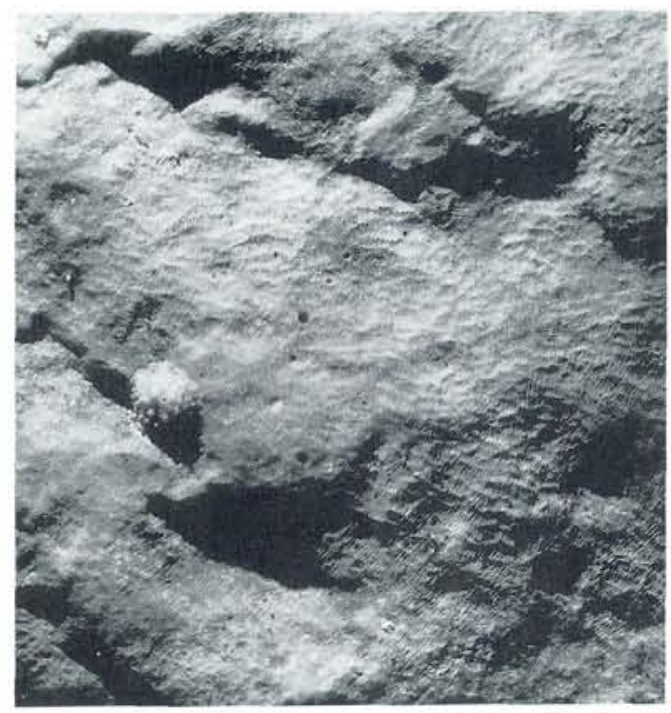

Fig. 8. Chiton radulation traces on test block no. $7, \times 4$.

echinoids. Adult individuals may wander in from the surrounding seafloor, but this is unusual for these territorially restricted animals. Normally, it seems, the new substrate is colonized by larvae, as at first only juveniles are present. The substrate offers a niche for these browsers as soon as it has been sufficiently invaded by endolithic algae and cyanophytes. Probably this food source develops during the first winter and spring, and the browsers arrive with the next breeding season in the early summer.

Browsing by chitons and echinoids involves considerable substrate removal (figs 8 \& 9) (Krumbein \& Van der Pers 1974; Bromley 1975; Farrow \& Clokie 1979; Akpan \& Farrow 1984).

On the test blocks, the chiton fauna was dominated by a single species, Chiton olivaceus. By October of year one, a single chiton juvenile may exploit a territory of $100 \mathrm{~cm}^{2}$, ; many samples bear several individuals, bioeroding the entire under side of the sample. In a few samples, however, patches of surface have escaped this treatment.

Echinoids were encountered more sporadically on the samples. Of the three species that are common in the area, only Paracentrotus lividus has been found on first year samples, but the characteristic bioerosion sculpture of echinoids covers extensive areas of undersides of several slabs (fig. 9).

This rasping process rendered the microtopography of all surfaces generally similar, whether they originally were highly polished or a rough fracture.

Foraminifera in pits. A foraminifer has colonized especially upper surfaces but also other places that are relatively little browsed by chitons. Individuals produce pits that closely enclose them. The foraminifera attain maximum abundance on blocks that are 3 years old; they are at present under study by H. J. Hansen and R. G. Bromley (in prep.).

\section{Subsequent years}

The processes initiated within the first year intensify in the second. The chitons and echinoids reach adult size and all available territory is occupied (fig. 10). The history of these processes in subsequent years, however, varies greatly according to the setting of the individual sample.

Stable, heavy samples: equilibrium

On samples that are physically stable and free from sedimentation hazards, the epilithic and endolithic communities develop towards maturity. Adult echinoids may colonize the block and, in fair weather, move onto upper surfaces to browse. The algal meadow is locally removed by this, giving access to endoliths. The first boring sponges probably appear in year one, but are

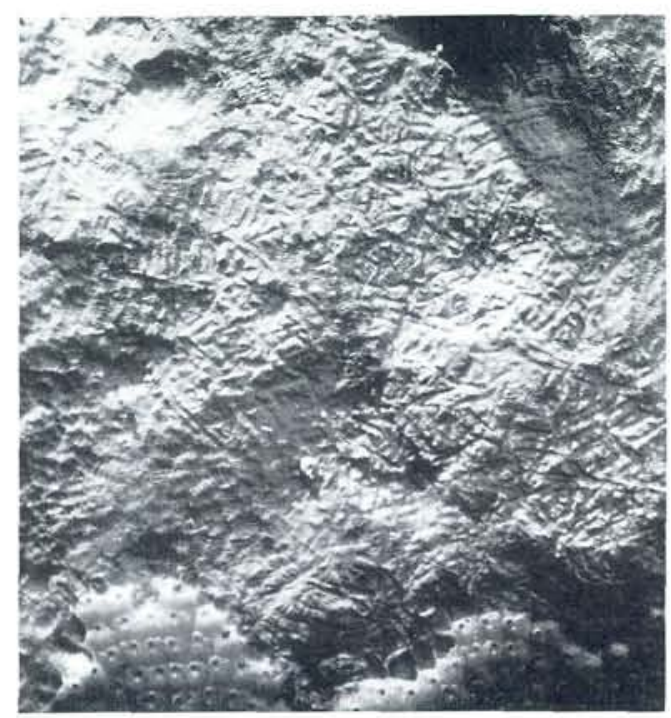

Fig. 9. Gnawing traces of a juvenile echinoid on test block no. $7, \times 4$. 


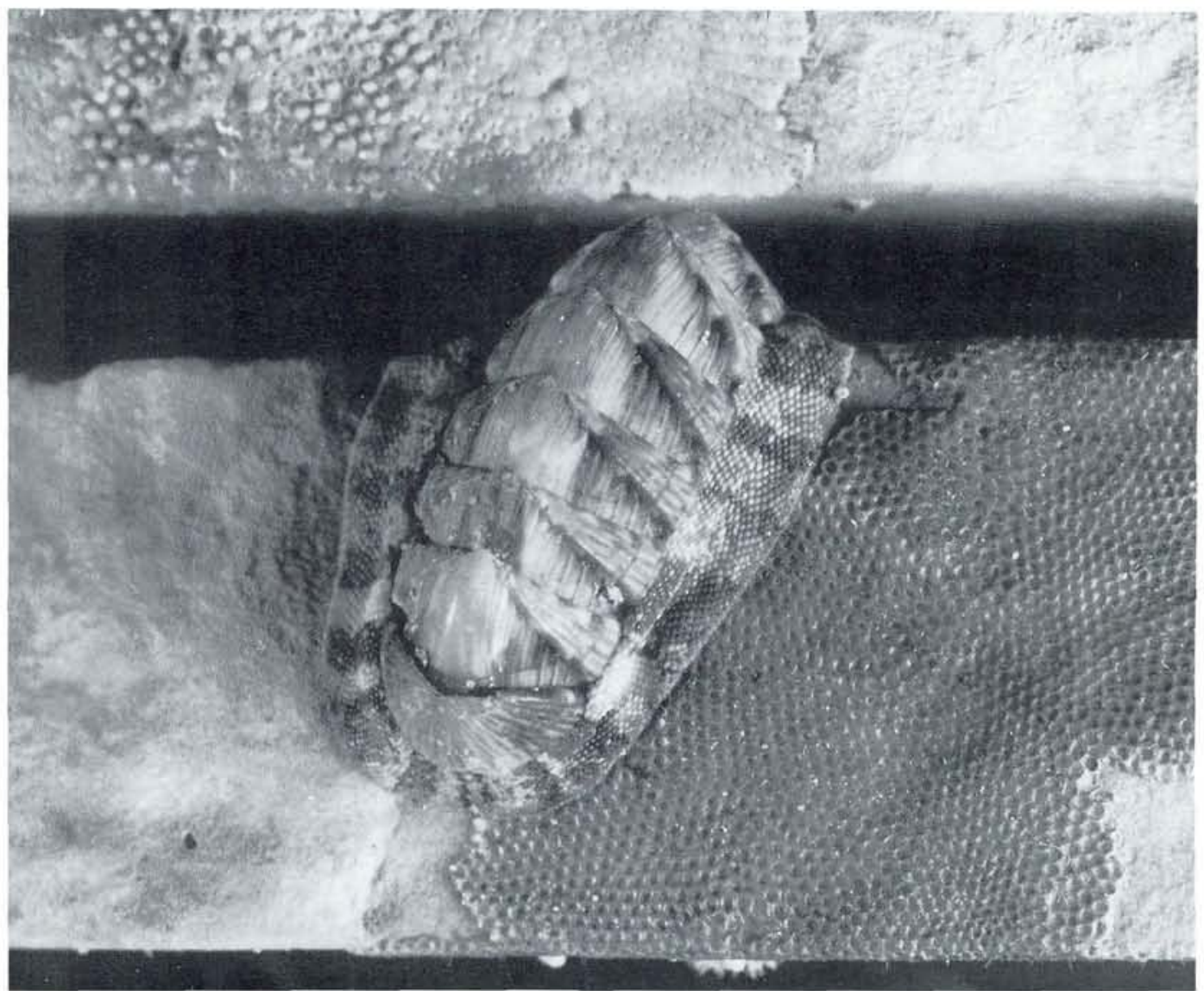

Fig. 10. Chiton olivaceus emerging from a slit in test block no, $7, \times 3.5$. Note the radulation traces in its shadow to the right, and the unabraded bryozoans.

sparse and minute. In year two the juvenile sponges first become readily visible, but remain sparse (fig. 11). Their rapid growth and diversification are noticeable in following years. After five years, sample 21 (figs 12 \& 13) contained at least 16 individual endolithic sponges more than $1 \mathrm{~cm}^{2}$ in area, and representing about 5 species, including Cliona rhodensis, $C$. ?celata, $C$. viridis, and $C$. vastifica.

On under sides of many blocks, the rate of net bioerosion by chitons appears to diminish. This is largely because coralline algae become established, and a trophic balance develops between them and the browsers. Adey (1973) and Steneck $(1982 ; 1983)$ showed that while coralline algae actually benefit from chiton erosion through the removal of epiphytes, some even depend on it for healthy growth. Chiton grazing is balanced by algal growth. A similar balance is noted in connection with echinoid grazing (Dayton 1975; Ayling 1981; Sebens 1985).

Endolithic sponges eventually enter the under surface and thrive there, particularly because of the chiton/alga balance which stabilizes the substrate surface. The protection from sediment accumulation enjoyed by the downward facing surface also promotes sponge growth; the majority of sponge bioerosion is connected to this surface.

Unstable, small samples: opportunism. In unstable plates, where flipping over and transport disturbs the sample in winter storms, the surfaces do not mature and the early phases of bioerosion remain active. When an under surface is turned upwards, an algal meadow smothers the coralline 


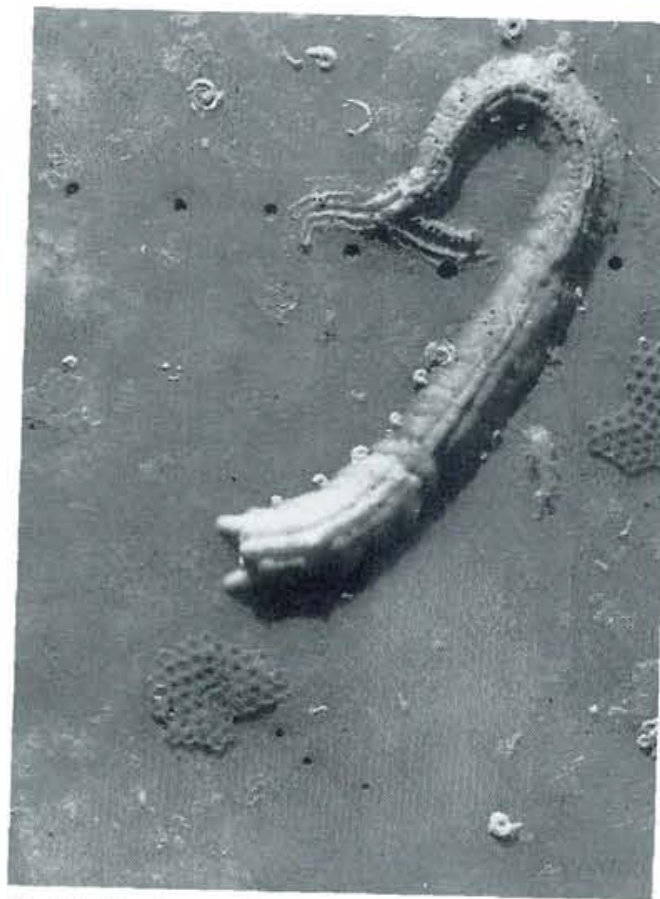

Fig. 11. After 2 years of submergence, this part of the surface of test block no. 8 has suffered little attention from echinoids and chitons. The bryozoans are undamaged but the juvenile parts of the Serpula vermicularis tube are broken away. All surfaces are tinted by boring algae, except the newest portion of the tube, which is still pristine. The borings of two endolithic sponges are visible as chains of apertures for papillae. The lower is that of Cliona schmidti, the upper perhaps $C$. vermifera. $\times 5$ alga. Likewise, the turning over of the upper surface places this within the regime of the chitons where, unprotected by algal crust, the substrate is attacked directly. If cobble tumbling occurs often no stability is reached in the hard substrate communities. Samples of this type show advanced chiton and echinoid radulation exclusively. Clearly, these bioeroders are opportunistic members of the bioerosional community sequence.

Brachiopods. The micromorph terebratelloid brachiopods Argyrotheca cordata and A. cuneata play an insignificant role in bioerosion. Their stout pedicles have short papillae that bore into the substrate (Bromley \& Surlyk 1973). The two species are common in cryptic habitats in the study area. In the test blocks, therefore, it is not surprising that they have only been met with on two slitted blocks. Only juvenile brachiopods were found, these within slits, where they were out of reach of at least adult chitons and echinoids. They comprise three size classes, representing the release of three groups of brooded larvae of the year the blocks were lifted; the latest spatfall occurred within about a month before retrieval.

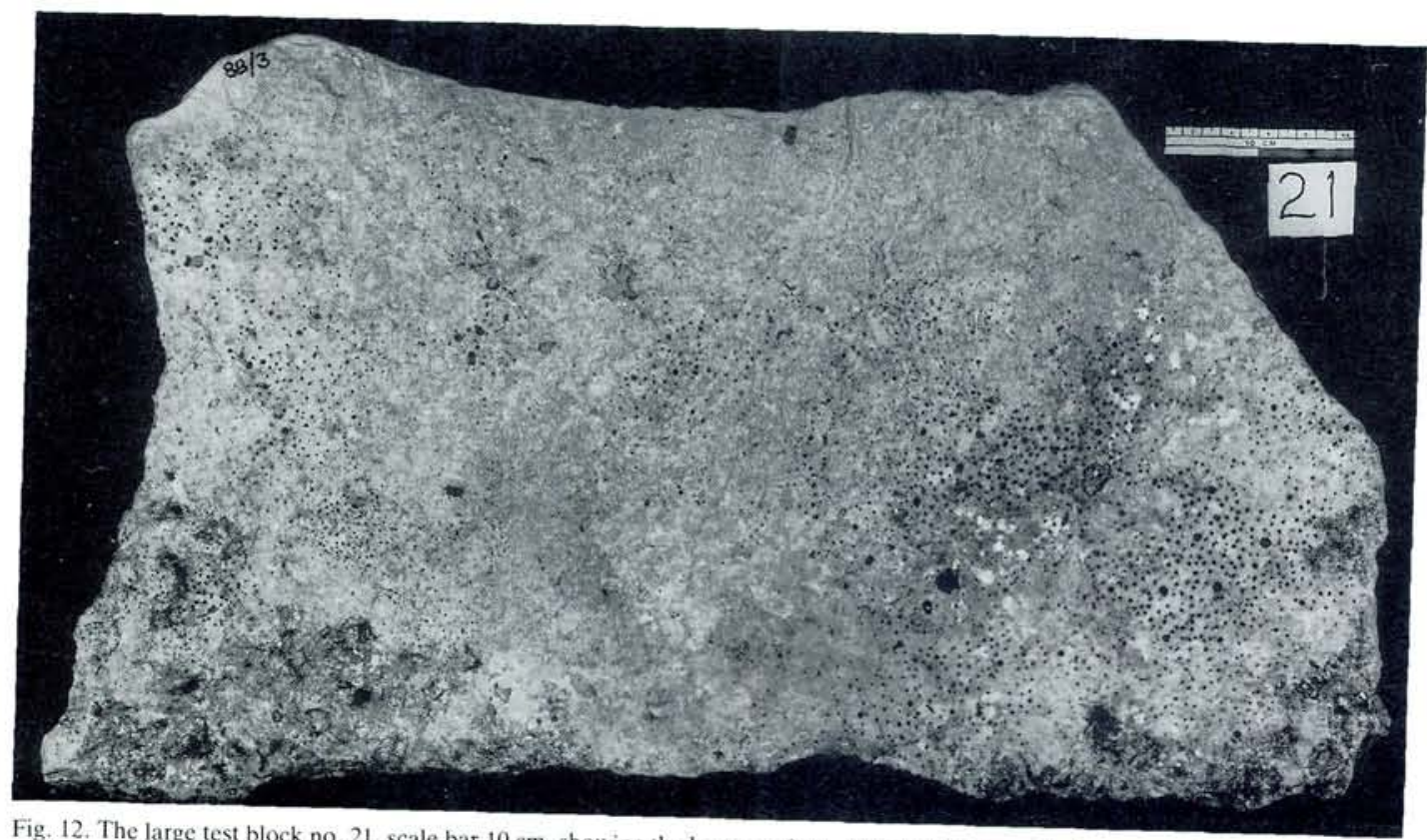
Fig. 12. The large test block no. 21 , scale bar $10 \mathrm{~cm}$, showing the lower surface. All parts are irregular fracture surfaces. The block lay
on the seafloor at locality $14 \mathrm{in}-3 \mathrm{~m}$ for 5 years and has been extensively colonized by boring sponges. 


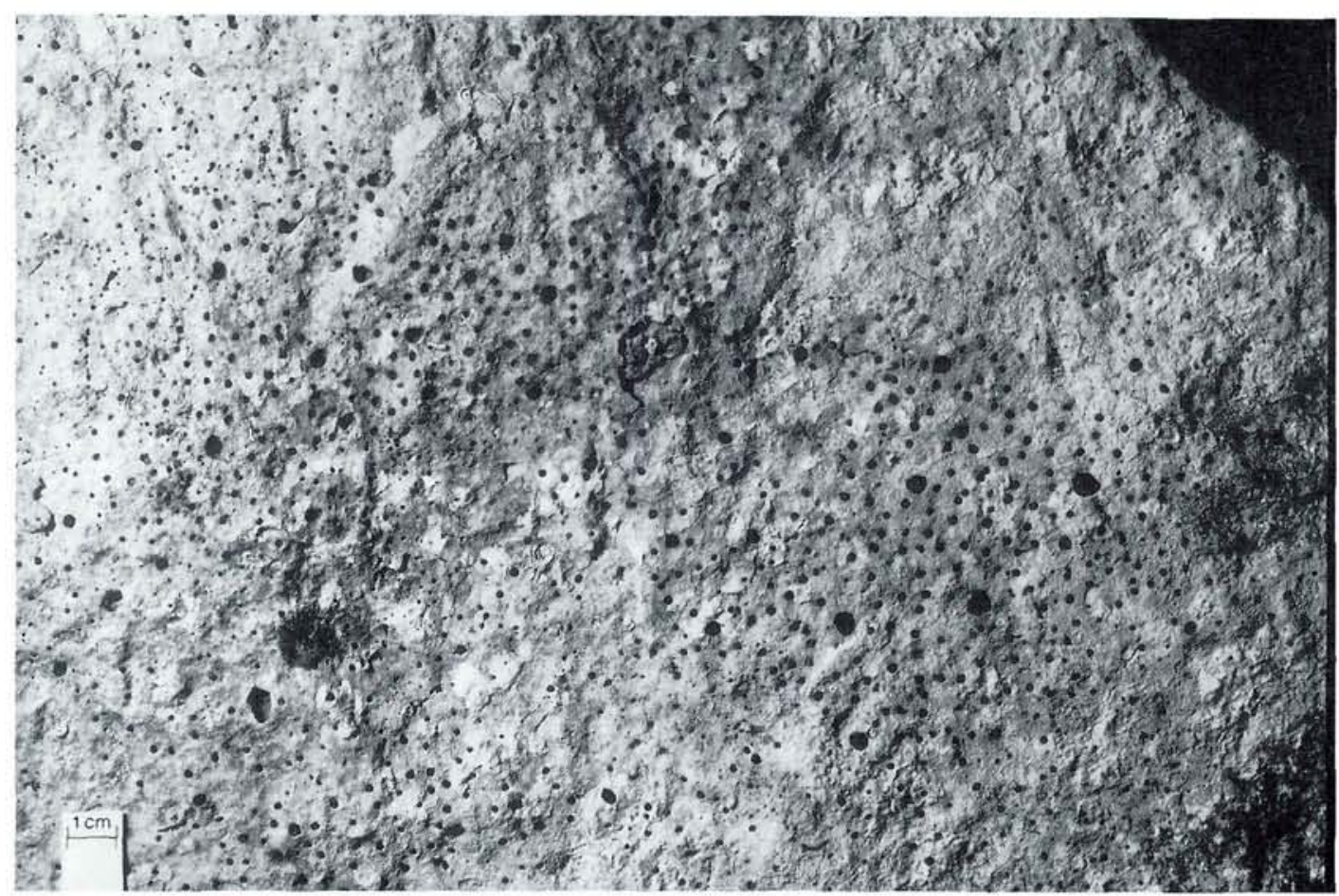

Fig. 13. Close-up of part of fig. 12 showing the apertures to papillae of a large individual of endolithic sponge, probably Cliona celata. $\times 0.5$.

\section{Discussion}

Rate of endolithic sponge growth

The study provides an opportunity to measure directly the size/age relationship of sponge borings. However the year of colonization has not been identified in all cases, and a maximum age only is available. In some cases, parts or all of the sponge were dead on retrieval, which again renders the period of growth uncertain.

Acker \& Risk (1985) documented the lateral growth rate of large, well-grown individuals of Cliona caribbaea at about $4 \mathrm{~cm} /$ year. This is higher than the rate of any species on our test blocks. The high rate may be explained by the large size of the individuals (growth of boring sponges accellerates with age: Korringa 1951; cf. Evans 1969); or else it may be due to physical disturbance through driving marker nails directly into the sponges (cf. Stoker 1897). Bergman (in Acker \& Risk 1985) recorded only $1 \mathrm{~cm} /$ year for Cliona viridis on the Great Barrier Reef, Austra- lia, a rate that compares better with those on our test blocks.

The species of sponges present on the blocks more of less follow the abundance or diversity patterns of the local community. In the surrounding seafloor, Cliona viridis is the most abundant species, followed by $C$. rhodensis; third most common is Cliothosa hancocki (Rützler \& Bromley 1981). On the test blocks, C. viridis is common, $C$. rhodensis is so far represented by a single individual and $C t$. hancocki has not yet been recognized. Less conspicuous species of sponge occur commonly on the blocks: $C$. schmidti, C. ?celata and C. vastifica. The relative abundance of these species in the surrounding substrate is not known.

\section{Unrepresented groups}

The surrounding seafloor contains a bioeroding community that is different from that found in the samples to date. Thus, community equilibrium does not yet seem to have been achieved. 


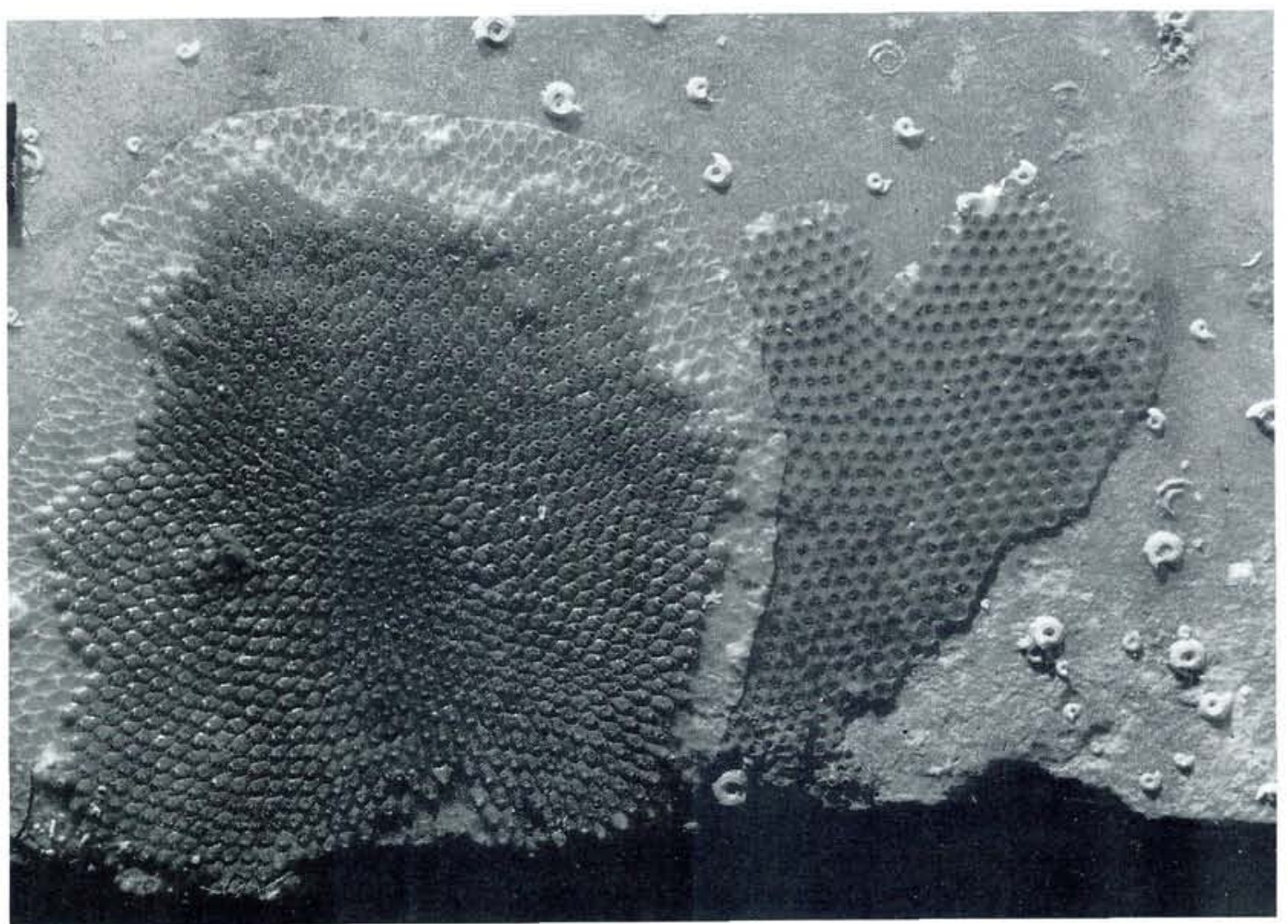

Fig. 14. Close-up of fig. 2. Two bryozoan colonies. To the right, Onychonella cf.angulosa overgrowing juvenile tubes of Spirorbis pagenstecheri. This is being overgrown in turn by Reptadeonella violacea. Test block no $8, \times 5$.

The reasons for the discrepancy, however, are not clear.

No patellid gastropods have been found on the samples. Neither has their characteristic bioerosion sculpture been recognized (e.g., Bromley \& Hanken 1981). However, as Schneider (1976) pointed out, patellid gastropods are most abundant at sea level and extend only sparsely to $-10 \mathrm{~m}$ or so. The shallowest of our test blocks $(-3 \mathrm{~m})$ should not be too deep for patellid colonization. Chitons, in contrast, are sparse in the sea level zone and become more common below it.

The bivalves Lithophaga lithophaga and Gastrochaena dubia are both present in the seafloor but are lacking in the samples. Neither are as common here as further west in the Mediterranean, but their presence was expected in the test blocks.

Most surprising is the total absence of boring sipunculan and polychaete worms. These are extremely abundant in the surrounding rock whereas no single example has yet been observed in the test blocks.

\section{Community succession}

The sequence of appearance of bioeroding and encrusting organisms on the test blocks reveals a simple succession of communities (fig. 14). A similar succession, i.e. microalgal borers followed by browsers, has been recognized elsewhere on rocky coasts (Schneider 1976; Schneider \& Torunski 1983; Torunski 1979).

In several studies on community development of algae on cobbles (Lieberman et al. 1979; 1984; Davis \& Wilce 1987) it has been reported that herbivore populations are reduced relative to the surrounding massive rock surfaces. In the present study no such reduction has been observed; on the contrary, the chiton population seems to be denser in the second year on the test blocks (fig. 15) than on the surrounding rock floor. This dis- 


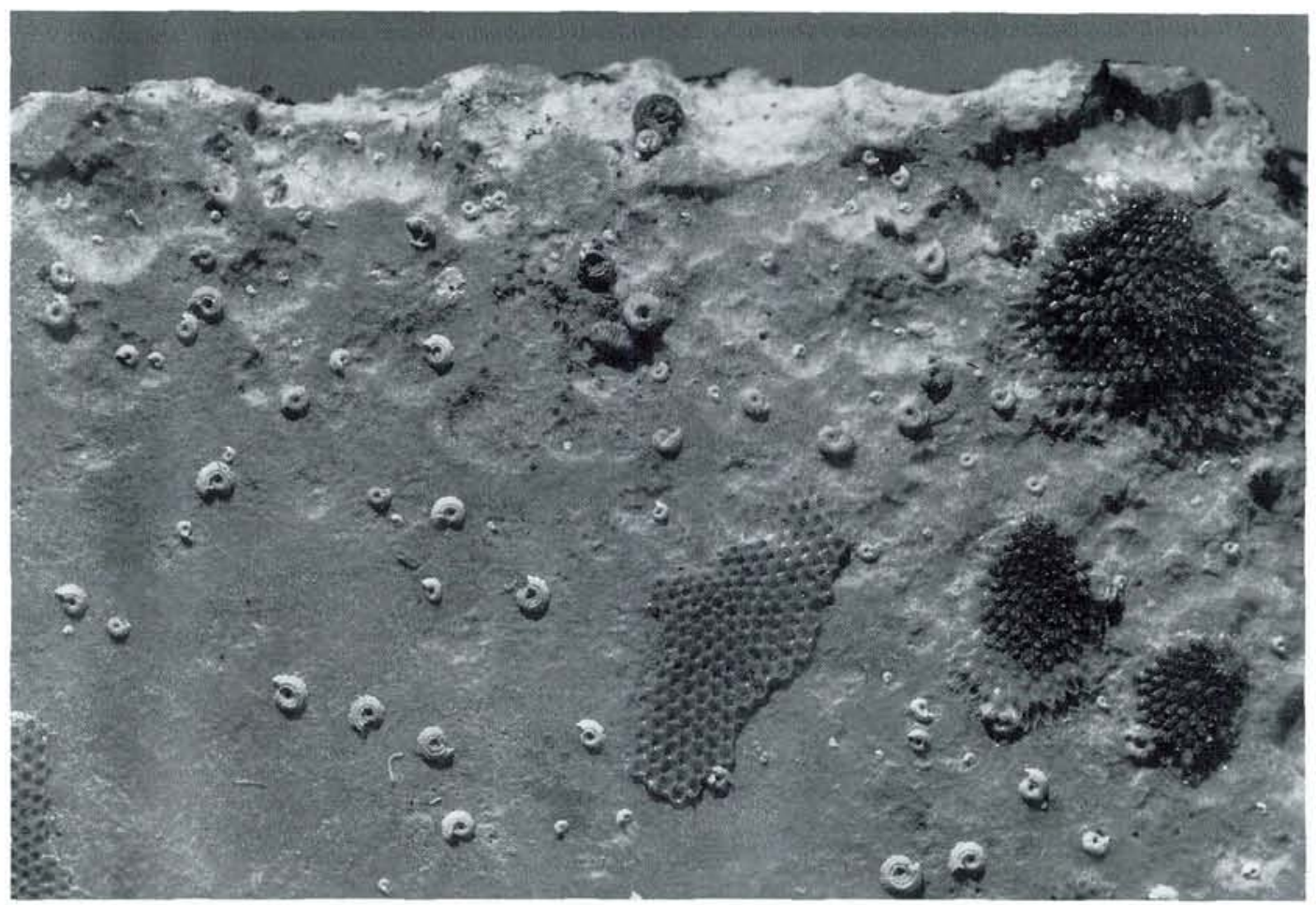

Fig. 15. Close-up of fig. 2. Advanced, cuspate radulation sculpture by chitons, both before and after encrustation by the small serpulid polychaete Spirorbis pagenstecheri and the bryozoans Reptadeonella violacea and Onychocella cf. angulosa. Note the juvenile chiton above centre. $\times 5$.

crepancy with the algal study areas may be due to the generally larger size of our blocks, which are only unstable in winter storm periods. This disturbance does not noticeably deter the herbivores.

On coral reefs, McCloskey (1970) briefly mentioned a succession of borers that comprised algae, sponges, worms and finally bivalves. It is the last two groups that are unexpectedly absent in the test blocks. From this slender evidence it might be suggested that the lack of otherwise abundant groups is simply a matter of immaturity of the communities, and that in future years we may expect to encounter them.

Choi (1964), on the other hand, found quite another pattern of succession on coral reef rubble. Perhaps it is premature to seek similarities in patterns in such divers environments and communities as Caribbean coral reefs and the eastern Mediterranean.
The effect of disturbance

Many studies of recruitment and development of epilithic communities have shown the importance of disturbance (e.g., Dayton 1971; 1975; Denslow 1980; Sousa 1980; 1984a, b; Dethier 1984; Sebens 1985). Two kinds of disturbance concern us here, physical and biological. Physical disturbance involves the tumbling of cobbles through wave action during storms and depends on the hydrodynamic conditions of the locality and the weight and shape of the block (Riedl 1964; Osman 1977). Biological disturbance concerns dominance by a predatory or grazing species of the community, be it fish (Talbot et al. 1978), echinoids (Dayton 1975; Ayling 1981; Lieberman et al. 1979; 1984) or the limpet-chiton guild (Dayton 1971).

The effect of both types of disturbance is to inhibit the maturation of the community and to expose patches of substrate surface for renewed colonization. Diversity may thus be raised by the prolonged retention of opportunistic species in 
the community (Sousa 1979a, b; Taylor \& Littler 1982).

The endolithic community is also strongly affected by disturbance, although not precisely as the epiliths are. The concealed endoliths are less vulnerable to damage by tumbling than are epiliths. Nevertheless, it is clear from our results that hardly any macroendolithic recruitment has occurred on the physically most disturbed blocks.

Biological disturbance by chiton and echinoid grazing should inhibit recruitment of endoliths, but once they are established, this surface clearing should benefit endolithic development. The chiton-echinoid/coralline algal association is of general occurrence and should represent an ideal habitat for bioeroding communities. The preservability of both the algal skeleton and the characteristic rasping traces should also render this system recognizable in the fossil record. On the test blocks, it takes at least two years, usually more, for this balance to be achieved.

\section{Alternate stable states}

Although the communities on our test blocks are extremely heterogeneous and patchy, it is possible that several alternative equilibria are represented, which Sutherland (1974) called "alternate stable states". Thus, a community containing a chiton on one cobble may exist side by side with one lacking a chiton. These communities on each their "island habitat" will have completely different constitutions, and yet each represents a permanent equilibrium. Two such communities may occupy upper and lower surfaces of the same block. Whereas this development is obvious in the more rapidly maturing epilithic communities, it is too early to say whether alternate stable states ultimately also will be reflected in the endolithic communities.

\section{Timing of colonization}

Another factor that may play a role is the seasonality of recruitment and the timing of sampling (Bélanger \& Cardinal 1977; Sousa 1984b). The presence of only minute and very rare boring sponges at the end of the first year may be due to the late reproduction of these animals in summer. Larval metamorphosis in, say, June might lead to so little growth by October that the juveniles have been overlooked among the rough chitonproduced microtopography.

Tunnicliffe (1982, p. 311) "observed the presence of" boring sponges in test blocks of coral skeleton after only 10 months of exposure (but how much bioerosion and which months of the year were not mentioned). After two years her test blocks showed "considerable erosion by sponges". This might imply more rapid growth than in our sponges. If, however, we had laid out our test blocks just before the summer sponge breeding season, we might have detected their bioerosion after less than 10 months. Thus, the precise timing of short-term experiments of this kind is critical.

\section{Conclusions}

The rate of bioerosion observed in the test blocks is slower than we had expected. Almost no sponge boring was seen before year two and some blocks still contain none after six years of continuous exposure.

Covering by sediment for even short periods smothers the bioeroding community. Recolonization of such a surface after reexposure to sea water may be more rapid than the original colonization as the intricate bioerosion sculpture provided by the pre-burial borings will offer protected niches for settling larvae.

The efficient bulldozing of entire surfaces by chitons is most impressive and must play a major role in inhibiting recruitment of boring organisms. Juvenile chitons enter the smallest crannies and clean off the surfaces. Only microsculpture escapes their attentions. Nevertheless, epilithic bryozoans and serpulids manage to obtain a foothold in chiton territories, so borer larvae should have access also. The absence of boring bivalves and worms therefore is not adequately explained.

Our results suggest that the thoroughly bored rockground and shell surfaces so common in the fossil record represent several years of uninterrupted exposure to sea water.

\section{Acknowledgements}

Many of our students and friends have braved the chill Greek 
waters in order to help emplace heavier blocks on the seafloor. In particular we thank Ludvig Beckman for placing his special powers of levitation at our disposal.

\section{Dansk sammendrag}

Fors $\emptyset \mathrm{g}$ af 1 til 2 års varighed har været foretaget med udlægning af kalk-prøveblokke på lavt vand for at måle, hvor hurtigt bioerosion foregår, og $\mathrm{j}$ hvilken rækkefølge de bioeroderende organismer indfinder sig. Forsøgene blev udført i tropiske koralrevsmiljøer og viste en forbløffende nedbrydningshastighed. Vi har valgt en periode på minimum 10 år med udlægning og gradvis optagning af marmor- og kalkstensplader og -blokke (fra 1 til $50 \mathrm{~kg}$ ) i -3 til $-17 \mathrm{~m}$ i det østlige Middelhav ved en kalkstenskyst på Rhodos, Grakenland. Resultaterne af de første 6 år viser, at kolonisationen ved bioeroderende organismer ikke direkte er afhængig af, hvor længe substratet har været udsat; men hvor stabilt den enkelte blok har ligget. På blokke, der regelmæssigt tumles af vinterstorme, opnår den epi- og endolitiske flora og fauna ikke ligevagt og modenhed. Uforstyrrede blokke viser en succession af organismer og en nedbrydning, der er betydelig langsommere end beskrevet for troperne. Efter 6 år har de mest iøjnefaldende borende organismer i området (børsteorme, sipunculide orme og boremuslinger) endnu ikke koloniseret blokkene. Borende alger og spongier har hurtigt indfundet sig; men deres spredning og erosion påvirkes af balancen mellem epilitiske organismer og raspende skallus, snegle og søpindsvin. Det langsomme tempo bioerosionen i dag skrider frem i gør, at man ved studiet af fossile, stærkt bioeroderede kalkstensblokke og -kystklinter skal regne med at substratet har været blottet for angreb gennem adskillige år og ikke som hidtil antaget måneder.

\section{References}

Acker, K. L. \& Risk, M. J. 1985. Substrate destruction and sediment production by the boring sponge Cliona caribbaea on Grand Cayman Island. Journal of Sedimentary Petrology 55: 705-711.

Adey, W. H. 1973. Temperature control of reproduction and productivity in subarctic coralline algae. Phycologia 12: 111-118.

Akpan, E. B. \& Farrow, G. E. 1984. Depth of deposition of Early Holocene raised sediments at Irvine deduced from algal borings in mollusc shells. Scottish Journal of Geology 20: $237-247$.

Ayling, A. M. 1981. The role of biological disturbance in temperate subtidal encrusting communities. Ecology 62: 830847.

Bélanger, C. \& Cardinal, A. 1977. Stades initiaux de colonisation de substrats durs dans la Baie-des-Chaleurs, Québec. Marine Biology 44: 27-38.

Bromley, R. G. 1975. Comparative analysis of fossil and recent echinoid bioerosion. Palaeontology 18: 725-739.

Bromley, R. G. \& Hanken, N.-M. 1981. Shallow marine bioerosion at Vardø, arctic Norway. Bulletin of the Geological Society of Denmark 29: 103-109.

Bromley, R. G. \& Surlyk, F. 1973. Borings produced by brachiopod pedicles, fossil and Recent. Lethaia 6: 349-365.

Choi, D. R. 1964. Ecological succession of reef cavity-dwellers (coelobites) in coral rubble. Bulletin of Marine Science 35: 72-79.

Davis, A. N. \& Wilce, R. T. 1987. Algal diversity in relation to physical disturbance: a mosaic of successional stages in a subtidal cobble habitat. Marine Ecology - Progress Series 37: 229-237.
Dayton, P. K. 1971. Competition, disturbance, and community organization: the provision and subsequent utilization of space in a rocky intertidal community. Ecological Monographs 41: 351-389.

Dayton, P. K. 1975. Experimental evaluation of ecological dominance in a rocky intertidal algal community. Ecolog. ical Monographs 45: 137-159.

Denslow, J.S. 1980. Patterns of plant species diversity during succession under different disturbance regimes. Oecologia 46: 18-21.

Dethier, M.N. 1984. Disturbance and recovery in intertidal pools: maintenance of mosaic patterns. Ecological Monographs 54: 99-118.

Ekdale, A. A., Bromley, R. G. \& Pemberton, S. G. 1984. Ichnology. Trace fossils in sedimentology and stratigraphy. Society of Economic Paleontologists and Mineralogists, Short course 15: $317 \mathrm{pp}$.

Evans, J. W. 1969. Borers in the shell of the sea scallop, Placopecten magellanicus. American Zoologist 9: 775-782.

Farrow, G. E. \& Clokie, J. 1979. Molluscan grazing of sublittoral algal-bored shells and the production of carbonate mud in the Firth of Clyde, Scotland. Transactions of the Royal Society of Edinburgh 70: 139-148.

Fischer, R. 1981. Bioerosion of basalt of the Pacific coast of Costa Rica. Senckenbergiana Maritima 13: 1-41.

Golubic, S. \& Schneider, J. 1979. Carbonate dissolution. Studies in Environmental Science 3: 107-129.

Kobluk, D. R., James, N.P. \& Pemberton, S. G. 1978. Initial diversification of macroboring ichnofossils and exploitation of the macroboring niche in the lower Paleozoic. Paleobiology 4: 163-170.

Kobluk, D.R. \& Risk, M.J. 1977. Rate and nature of infestation of a carbonate substratum by a boring alga. Journal of Experimental Marine Biology and Ecology 27: 107115.

Korringa, P. 1951. The shell of Ostrea edulis as a habitat. Archives Néerland. de Zoologie 10: 32-152.

Krumbein, W.E. \& Van der Pers, J.N.C. 1974. Diving investigations on biodeterioration by sea-urchins in the rocky sublittoral of Helgoland. Helgoländer wissenschaftliche Meeresuntersuchungen 26: 1-17.

Leloup, E. \& Volz, P. 1938. Die Chitonen (Polyplacophoren) der Adria. Thalassia 2: 63pp.

Lieberman, M., John, D. M. \& Lieberman, D. 1979. Ecology of subtidal algae on seasonally devastated cobble substrates off Ghana. Ecology 60: 1151-1161.

Lieberman, M., John, D. M. \& Lieberman, D. 1984. Factors influencing algal species assemblages on reef and cobble substrata off Ghana. Jour. exper. mar. Biol. Ecol. 75: 129-143.

Martindale, W. 1976. Calcareous encrusting organisms of the Recent and Pleistocene reefs of Barbados, West Indies. Ph.D thesis, University of Edinburgh, 178pp.

May, J. A. \& Perkins; R. D. 1979. Endolithic infestation of carbonate substrates below the sediment-water interface. Journal of Sedimentary Petrology 49: 357-378.

McCloskey, L. R. 1970. The dynamics of the community associated with a marine scleractinian coral. Int. Revue ges. Hydrobiol. 55: 13-81.

Mook, D.H. 1981. Effects of disturbance and initial settlement on fouling community structure. Ecology 62: 522-526.

Orombelli, G. \& Pozzi, R. 1967. Il Mesozoico nell'isola di Rodi (Grecia). Rivista Italiana di paleontologia e Stratigrafia 73: 409-536.

Osman, R.W. 1977. The establishment and development of a marine epifaunal community. Ecological Monographs 47: 37-63.

Palmer, T. 1982. Cambrian to Cretaceous changes in hardground communities. Lethaia 15: 309-323.

Perkins, R. D. \& Tsentas, C. I. 1976. Microbial infestation of 
carbonate substrates planted on the St. Croix shelf, West Indies. Bulletin of the Geological Society of America 87: 1615-1628.

Poulicek, M., Jaspar-Versali, M. F. \& Goffinet, G. 1981. Etude expérimentale de la dégradation des coquilles de mollusques au niveau des sédiments marins. Bulletin de la Société Royale des Sciences de Liège 50: 513-518.

Riedl, R. 1964. Die Erscheinungen der Wasserbewegung und ihr Wirkung auf Sedentarier im mediterranen Felslitoral. Helgoländer wiss. Meeresunters. 10: 155-186.

Rützler, K. 1975. The role of burrowing sponges in bioerosion. Oecologia 19: 203-216.

Rützler, K. \& Bromley, R.G. 1981. Cliona rhodensis, new species (Porifera: Hadromerida) from the Mediterranean. Proceedings of the Biological Society of Washington 94: 1219-1225.

Ryder, J. 1879. On the destructive nature of the boring sponge, with observations on its gemmules or eggs. American Naturalist 13: 279-283.

Schneider, J. 1976. Biological and inorganic factors in the destruction of limestone coasts. Contributions to Sedimentology 6: $112 \mathrm{pp}$.

Schneider, J. \& Torunski, H. 1983. Biokarst of limestone coasts, morphogenesis and sediment production. P.S.Z.N.I.: Marine Ecology 4: 45-63.

Sebens, K.P. 1985. The ecology of the rocky subtidal zone. American Scientist 73: 548-557.

Sousa, W. P. 1979a. Disturbance in marine intertidal boulder fields: the nonequilibrium maintenance of species diversity. Ecology 60: 1225-1239.

Sousa, W.P. 1979b. Experimental investigations of disturbance and ecological succession in a rocky intertidal algal community. Ecological Monographs 49: 227-254.

Sousa, W.P. 1980 . The responses of a community to disturbance: the importance of successional age and species' life histories. Oecologia 45: 72-81.

Sousa, W.P. 1984a. Intertidal mosaics: patch size, propagule availability, and spatially variable patterns of succession. Ecology 65: 1918-1935.
Sousa, W.P. 1984b. The role of disturbance in natural communities. Annual Review of Ecology and Systematics 15: 353391.

Steneck, R.S. 1982. A limpet-coralline alga association: adaptations and defences between a selective herbivore and its prey. Ecology 63: 507-522.

Steneck, R.S. 1983. Escalating herbivory and resulting adaptive trends in calcareous algal crusts. Paleobiology 9: 44-61.

Stoker, B. 1897. Dracula. Garden City: New York. ix + 354 pp.

Sutherland, J. P. 1974. Multiple stable points in natural communities. American Naturalist 108: 859-873.

Sutherland, J.P. \& Karlson, R.H. 1977. Development and stability of the fouling community at Beaufort, North Carolina. Ecological Monographs 47: 425-446.

Talbot, F. H., Russell, B. C. \& Anderson, G. R. V. 1978. Coral reef fish communities: unstable, high-diversity systems? Ecological Monographs 48: 425-440.

Taylor, P. R. \& Littler, M. M. 1982. The roles of compensatory mortality, physical disturbance, and substrate retention in the development and organization of a sand-influenced, rocky-intertidal community. Ecology 63: 135-146.

Torunski, H. 1979. Biological erosion and its significance for the morphogenesis of limestone coasts and for nearshore sedimentation (northern Adriatic). Senckenbergiana Maritima 11: 193-265.

Tudhope, A.W. \& Risk, M. J. 1985. Rate of dissolution of carbonate sediments by microboring organisms, Davies Reef, Australia. Journal of Sedimentary Petrology 55: 440 447.

Tunnicliffe, V. 1982. The role of boring sponges in coral fracture. Colloques Internationaux du C.N.R.S. 291: 309-315.

Warme, J.E. 1975. Borings as trace fossils, and the processes of marine bioerosion. In: Frey, R. W. (ed.) The study of trace fossils, 181-227. Springer: New York.

Wilson, M. A. 1987. Ecological dynamics on pebbles, cobbles, and boulders. Palaios 2: 594-599. 